\title{
Measles and immunological amnesia
}

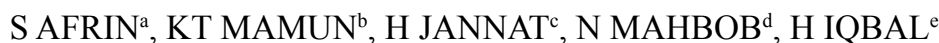

\begin{abstract}
:
Measles virus remains the most important cause of childhood mortality, causing a transient immunosuppression that accompanies and follows measles making the patients susceptible to secondary infections accounting for most of the measles-related complications and deaths. The majority of measles virus in the body uses Signaling Lymphocyte Activation Molecule (SLAM) as a receptor and only a minority of the virus may also use CD46. Infection and subsequent demise of SLAM cells may explain the severe immunosuppressive characteristic of this viral disease. Measles also reduce the nonspecific naüve $B$ cells in the bone marrow, which fight unfamiliar infections and SLAM signaling intensifies CD95-mediated apoptosis of B cells. Furthermore, in experimentally infected
\end{abstract}

\section{Introduction:}

Measles virus, one of the most contagious of human pathogens, can lead to severe complications having disastrous effects on the quality of life of the patients, their families and the country. Since 2000 measles vaccination has prevented an estimated 21 million deaths worldwide. However, the resurgence of measles is occurring and the reasons include suboptimal vaccine delivery due to lack of access to health services or resistance to vaccination based on nonscientific misconception, paucity of concern about disease severity and extensive international

a. Dr. Sabrina Afrin, MD (Virology), Lecturer, Department of Microbiology, Popular Medical College, Dhaka.

b. Kazi Taib Mamun, MPH, Research Investigator, icddrb.

c. Dr. Hasnatul Jannat, MPhil (Microbiology), Lecturer, Department of Microbiology, Popular Medical College, Dhaka.

d. Dr. Nabeela Mahboob, MD (virology), MPH, Assistant Professor, Department of Microbiology, Popular Medical College, Dhaka.

e. Dr. Hasina Iqbal, MPhil (Microbiology), Associate Professor, Department of Microbiology, Popular Medical College, Dhaka.

Address of Correspondence: Dr. Sabrina Afrin, MD (Viroogy), Lecturer, Department of Microbiology, Popular Medical College, Dhaka. E-mail: sabrinaafrin19@gmail.com, Cell: 01610540105

Received: 18 March, 2020

Accepted: 12, July, 2020 non-human primates (NHPs) measles virus infects and depletes pre-existing memory lymphocytes, causing immune amnesia. Results from different studies explain the long-term immunologic sequelae of measles resulting in overall childhood infectious disease mortality. As measles infection is tightly coupled to measles-associated immune memory loss, advancement in research regarding post measles immunological amnesia is needed to investigate immune pathogenesis and host immune responses.

Key Words: Immunological amnesia, Signaling Lymphocyte Activation Molecule, Memory B cells and naïve B cells, Memory CD4+ and CD8+T cells.

(J Bangladesh Coll Phys Surg 2020; 38: 191-196)

DOI: https://doi.org/10.3329/jbcps.v38i4.48980

travel. ${ }^{1}$ The impact of delayed mortality as a result of measles infection is only now being realized. The increased incidence raises concerns about the linkage of measles and prolonged impairment of acquired immunological memory. There is evidence that those who survived measles infection, the virus left a lasting mark - 'immunological amnesia.' The amnesic immune system renders individuals more susceptible to other pathogens bringing new insights on this viral infection. ${ }^{2}$ Children who suffered from measles infection continue to experience higher levels of mortality and morbidity over the long term requiring increased antimicrobial therapies which supports the hypothesis that measles has a prolonged negative impact on the immune system of the host. ${ }^{3}$

The concept of immunological amnesia:

Immunological amnesia may be defined as compromising the immune system's memory, causing the body to forget immunity it had developed to other pathogens in the past. Recent studies invoked this hypothesis that after measles infection, the host immune systems get crippled and fail to protect against previously encountered pathogens. ${ }^{4}$

Cellular receptors for measles virus:

Measles virus is a non-segmented, negative-stranded RNA virus with two envelope glycoproteins, the 
haemagglutinin $(\mathrm{H})$ and fusion $(\mathrm{F})$ proteins, which mediate receptor binding and membrane fusion, respectively. ${ }^{5}$ CD46 was shown to be a cellular receptor for the Edmonston and Halle laboratory strains of measles virus ${ }^{6}$, which is a complement regulatory molecule that is expressed on all nucleated cells in humans. ${ }^{7}$ On the other hand, wild-type measles virus strains isolated in the marmoset $\mathrm{B}$ cell line B95a or human B cell lines were found usually to use a molecule other than CD46 as a cellular receptor, which is Signaling Lymphocyte Activation Molecule (SLAM) also known as CD150. It is a membrane glycoprotein involved in lymphocyte activation. ${ }^{8}$ Another study showed that as the Edmonston strain, capable of using CD46 as a receptor, was unable to efficiently enter respiratory epithelial cells through the apical surface where CD46 is abundantly expressed. Thus, it was postulated that the initial targets of the measles virus in the respiratory tract were SLAM-positive cells of the immune system. ${ }^{9}$ Measles virus infects both T and B lymphocytes by the binding of the measles hemagglutinin $(\mathrm{H})$ glycoprotein to the SLAM. ${ }^{10}$ Human SLAM is expressed on immature thymocytes, CD45RO high memory T cells, and a proportion of B cells, and rapidly induced on all $\mathrm{T}$ and $\mathrm{B}$ cells following activation. ${ }^{11}$ High levels of SLAM are also found in Th1 cells, but only small amounts in the Th2 cells. ${ }^{12}$ It is noteworthy that none of the measles virus strains have been found that cannot use SLAM as a receptor, whereas only the Edmonston and some other strains can use, besides SLAM, CD46 as a receptor. ${ }^{13}$ Also, measles virus infection was inhibited by the anti-SLAM antibody. These results established that SLAM is a cellular receptor for measles virus. ${ }^{14}$

\section{Mechanism of measles-related immunological amnesia :}

How measles immunological amnesia happens and what is the mechanism of it is yet not fully understood, but there are several proposed mechanisms. Understanding the viral tropism of measles is one of the important aspects to unravel the mechanism or pathogenesis of immunological amnesia. As it is established that the majority of the measles virus in the body causes the engagement of SLAM as a receptor, and only a small minority may also use CD46. ${ }^{15}$ Infection with measles virus and subsequent destruction of SLAM cells may explain the severe immunosuppressive characteristic of measles. Although less well studied, another proposed contributing mechanism to immune suppression is killing activated lymphocytes and monocytes and mature dendritic cells. SLAM signaling also heightens CD95-mediated apoptosis of B cells. ${ }^{16}$ Furthermore, memory $\mathrm{T}$ cells and Th1 cells express high levels of SLAM provides some insight to the reason of suppressed delayed type hypersensitivity responses such as the tuberculin skin test in measles infected patients. $^{2}$ In experimentally infected non-human primates (NHPs) measles virus infects and makes a significant drop in pre-existing memory lymphocytes, causing immune amnesia. ${ }^{17,18}$ The depletion of functional memory CD8 T cells seems to have a significant impact on protective immunity. ${ }^{19} \mathrm{~A}$ measles outbreak in the Dutch community comes up with a unique opportunity to shed some light on this topic by studying the pathogenesis of measles immune suppression in unvaccinated children. In peripheral blood mononuclear cells (PBMC) of prodromal measles patients, measles virus infected memory CD4+ and CD8 $+\mathrm{T}$ cells were detected and naive and memory $\mathrm{B}$ cells at uniform levels as those observed in NHPs. In paired PBMC collected before and after measles infection showed reduced circulating memory $\mathrm{B}$ cells and increased regulatory $\mathrm{T}$ cells and transitional $\mathrm{B}$ cells after being infected with measles virus. ${ }^{20}$ Total numbers of $\mathrm{T}$ and $\mathrm{B}$ cells in peripheral blood were considerably decreased in the early acute measles patients in comparison to those of age-matched healthy controls, demonstrating measles-induced lymphopenia. It was demonstrated that in the CD4+ and CD8+ $\mathrm{T}$ cell populations, memory cells were predominantly infected. In the $\mathrm{B}$ cell population, both naive and memory cells were infected. ${ }^{17,} 18$ These findings reinforce the immune amnesia hypothesis. For investigating the hypothesis that measles induces 'immunological amnesia', in 2019, two different studies mount further evidence. Petrova and colleagues sequenced the immunoglobulin gene repertoire of naïve and memory B cells in paired pre and post measles infection blood samples from unvaccinated children. Memory B cell clones present before infection were depleted in post-measles samples even after lymphocyte counts had recovered. It appears that the virus is responsible for the demise 
of B cells specific to other pathogens, allowing new, measles specific memory B cells to replace them. Another contribution to cripple the immune system is that measles also decreased the diversity of another category of B cells: nonspecific naïve B cells in the bone marrow, which stand ready to fight unfamiliar infections. ${ }^{21}$ Around the same time Mina and colleagues assessed the diversity and magnitude of the antibody repertoires by using VirScan, a phage-display immune precipitation and sequencing technology that traces antibodies to thousands of pathogens in blood. This study was conducted among unvaccinated children before and 2 months after laboratory confirmed natural measles virus infection as well as in unimmunized children who remained uninfected by measles virus during the study. To compare the effect of measles between the pre and post measles infection antibody repertoire, epitopes detected at the first time point and retention or loss of epitope recognition of pre-existing pathogen specific antibody repertoires after severe or mild measles viral infection were measured. ${ }^{4}$

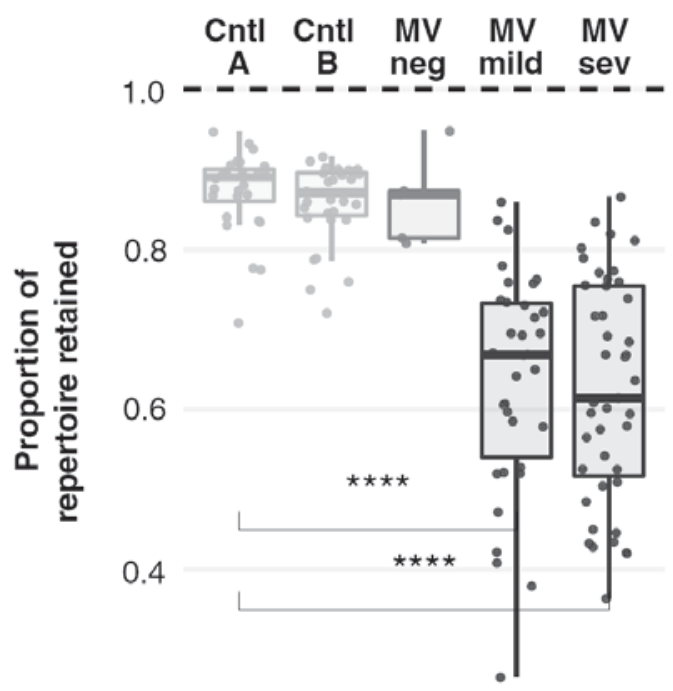

Fig.-1: The proportion of total epitopes detected before measles infection that were retained after measles infection. (Cntl A: age-matched controls samples collected at similar intervals as the measles cohorts, Cntl B: age-matched controls samples collected one year apart, MV neg: measles virus negative; unimmunized children who remained uninfected by measles virus during the study, $\boldsymbol{M V}$ mild: study participants with mild measles virus infection, MV sev: study participants with severe measles virus infection). One point represents one child. After severe or mild measles, children lost a median of $40 \%$ (range: 11 to 62\%) or 33\% (range: 12 to $73 \%$ ), respectively, of their total pre-existing pathogen specific antibody repertoires. However, 90\% of the controls retained their repertoires over similar or longer durations. Bonferroni-adjusted student's $t$ test $P$ values for significant differences relative to control $A$ are shown $(* * * * P<0.0001) .{ }^{4}$

These data imply that measles virus infection diminishes protective pre-existing pathogen specific antibodies that defend against viral and bacterial strains a person who was previously immune.

\section{How long does measles immunological amnesia persist:}

Measles induced immunological amnesia is transient but profound. ${ }^{22}$ It generally lasts for a period of several weeks to months. ${ }^{23,24}$ However for some people, it may be extended over 2 to 3 years which is of substantial clinical importance. ${ }^{4}$

\section{Effect of measles immunological amnesia}

In the last couple of years, progress towards measles elimination has stalled and there have been explosive outbreaks around the world. ${ }^{25}$ The global resurgence of measles virus raises concerns for childhood mortality as well as for immunological amnesia. Although in public view, measles is a benign childhood disease, due to erasure or significant reduction of the previously acquired immunity, immunological amnesia could be a danger over the long term. Secondary infections by other pathogens following acute infection of measles can lead to a sequence of unfortunate rise in morbidity and mortality among children. ${ }^{26,27}$

\section{Prevention of measles immunological amnesia:}

Before measles vaccination programs, measles infected over $95 \%$ of all children and was responsible for over 4 million deaths each year. ${ }^{28}$ However, measles remains a major global health threats to humans, causing more than 140000 deaths in $2018 .^{29}$ To combat measles World Health Organization 
(WHO) recommends 2 doses of measles vaccine for all children and at least 1 dose prior to international travel for adolescents and adults who are unsure about their immunity status. ${ }^{30}$ In 2019, member Countries of the WHO South-East Asia Region adopted a "Strategic Plan for Measles and Rubella Elimination 2020-2024" to prevent deaths and disabilities caused by these highly infectious childhood killer diseases. ${ }^{31}$ Despite measles is a vaccine-preventable disease, high transmissibility, propagated misinformation suggesting that the risk and consequences of measles are inconsequential. The measles vaccine phobia could be the reason behind widening pockets of unvaccinated children which not only increased measles outbreaks hitting several countries around the world today but also created a pathway for measles induced immunological amnesia. ${ }^{32}$ This concept of immunological amnesia should be envisioned as a long term risk factor, but this is of great hope that by protecting against measles infection, the vaccine prevents the body from losing or "forgetting" its immune memory and preserves its resistance to other infections afterward acute illness of measles. ${ }^{33,34}$

\section{Conclusion:}

The recent studies on immunological amnesia may help to explain why the majority of deaths and complications acquire after measles. However, understanding of the immunological amnesia is still in its infancy. Advanced research in this field is needed to develop strategies against this scourge as it is a major health complication for those afflicted otherwise and measles-related immunological amnesia might cause more deaths. Urgent efforts are needed to increase global coverage with two doses of routine measles vaccine, regular supplementary immunization activities and high-quality case-based surveillance.

\section{References}

1. Dabbagh A, Laws RL, Steulet C, Dumolard L, Mulders $\mathrm{MN}$, Kretsinger $\mathrm{K}$ et al. Progress Toward Regional Measles Elimination-Worldwide, 2000-2017. Morbidity and Mortality Weekly Report 2018; 67(47):1323. doi: 10.15585/mmwr.mm6747a6, PMid:30496160 PMCid:PMC6276384
2. Griffin DE. Measles Virus-Induced Suppression of Immune Responses. Immunological Reviews 2010; 236(1):176-89. doi: 10.1111/j.1600-065X.2010.00925.x, PMid:20636817 PMCid:PMC2908915

3. Gadroen K, Dodd CN, Masclee GM, De Ridder MA, Weibel D, Mina MJ et al. Impact and Longevity of Measles-associated immune Suppression: a Matched cohort Study Using data from the THIN General Practice Database in the UK. BMJ open 2018; 8(11): e021465. doi:http://dx.doi.org/10.1136/bmjopen-2017-021465, PMid:30413497 PMCid:PMC6231568

4. Mina MJ, Kula T, Leng Y, Li M, De Vries RD, Knip M et al. Measles Virus Infection Diminishes Pre-existing Antibodies that Offer Protection from Other Pathogens. Science 2019; 366(6465):599-606.doi: 10.1126/ science.aay6485, PMid:31672891

5. Hashiguchi T, Maenaka K, Yanagi Y. Measles Virus Hemagglutinin: Structural Insights into Cell Entry and Measles Vaccine. Frontiers in Microbiology 2011; 2:247. doi:https://doi.org/10.3389/fmicb.2011.00247, PMCid:PMC3267179

6. Manchester M, Eto DS, Valsamakis A, Liton PB, Fernandez-Muñoz R, Rota PA et al. Clinical Isolates of Measles Virus Use CD46 as a Cellular Receptor. Journal of Virology 2000; 74(9):3967-74. doi: 10.1128/ JVI.74.9.3967-3974.2000, PMid:10756008 PMCid:PMC111910

7. Cattaneo R. Four Vruses, Two Bacteria, and One Receptor: Membrane Cofactor Protein (CD46) as Pathogens' Magnet. Journal of Virology 2004; 78(9):4385-8. doi: 10.1128/JVI.78.9.4385-4388.2004, PMid:15078919 PMCid:PMC387720

8. Hsu EC, Iorio C, Sarangi F, Khine AA, Richardson CD. CDw150 (SLAM) is a Receptor for a Lymphotropic Strain of Measles Virus and May Account for the Immunosuppressive Properties of This Virus. Virology 2001; 279(1):9-21. https://doi.org/10.1006/viro.2000.0711, PMid:11145884

9. Ludlow M, Lemon K, de Vries RD, McQuaid S, Millar EL, van Amerongen G, et al. Measles Virus infection of Epithelial Cells in the Macaque Upper Respiratory Tract is Mediated by Subepithelial Immune Cells. Journal of Virology 2013; 87(7):4033-42. doi: 10.1128/JVI.03258-12, PMid:23365435 PMCid:PMC3624209

10. De Salort J, Sintes J, Llinàs L, Matesanz-Isabel J, Engel P. Expression of SLAM (CD150) Cell-surface Receptors on Human B-cell Subsets: from Pro-B to Plasma cells. Immunology Letters 2011; 134(2):129-36. doi:https://doi.org/ 10.1016/j.imlet.2010.09.021, PMid:20933013 
11. Jackson SM, Harp N, Patel D, Zhang J, Willson S, Kim YJ, et al. CD45RO Enriches for Activated, Highly Mutated Human Germinal Center B Cells. Blood, The Journal of the American Society of Hematology 2007; 110(12):3917-25. doi:https://doi.org/10.1182/blood- 2007-05-087767, PMid:17644737 PMCid:PMC2190611

12. Wang N, Morra M, Wu C, Gullo C, Howie D, Coyle T, et al. CD150 is a member of a Family of Genes that Encode Glycoproteins on The Surface of Hematopoietic Cells. Immunogenetics 2001; 53(5):382-94. doi:https://doi.org/ 10.1007/s002510100337, PMid:11486275

13. Tahara M,Takeda M, Seki F, Hashiguchi T, Yanagi Y, et al. Multiple Amino acid Substitutions in Hemagglutinin are Necessary for wild-type Measles Virus to Acquire the Ability to Use Receptor CD46 Efficiently. Journal of Virology 2007; 81(6):2564-72. doi:10.1128/JVI.02449-06, PMid:17182683 PMCid:PMC1865989

14. Tatsuo H, Ono N, Yanagi Y. Morbilliviruses Use Signaling Lymphocyte Activation Molecules (CD150) as Cellular Receptors. Journal of Virology 2001; 75(13): 5842-50. doi: 10.1128/JVI.75.13.5842-5850.2001, PMid:11390585 PMCid:PMC114299

15. Yanagi $Y$, Ono N, Tatsuo H, Hashimoto K, Minagawa H. Measles Virus Receptor SLAM (CD150). Virology 2002; 299(2):155-61. doi:https://doi.org/10.1006/viro.2002.1471, PMid:12202217

16. Hueber Ao, Koncz G. The Fas/CD95 Receptor Regulates the Death of Autoreactive B cells and the Selection of Antigen-specific B cells. Frontiers in Immunology 2012; 3:207-212. doi:https://doi.org/ 10.3389/fimmu.2012.00207, PMid:22848207 PMCid:PMC3404404

17. De Vries RD, McQuaid S, Van Amerongen G, Yüksel S, Verburgh RJ, Osterhaus AD, et al. Measles Immune Suppression: Lessons from the Macaque Model. PLoS Pathogens 2012; 8(8):e1002885. doi:https://doi.org/ 10.1371/journal.ppat. 1002885 ,PMid:22952446 PMCid:PMC3431343

18. Laksono BM, Grosserichter-Wagener C, de Vries RD, Langeveld SA, Brem MD, van Dongen JJ, et al. In Vitro Measles Virus Infection of Human Lymphocyte Subsets Demonstrates High Susceptibility and Permissiveness of Both Naive and Memory B cells. Journal of Virology 2018; 92(8):e00131-18. doi:10.1128/JVI.00131-18, PMid:29437964 PMCid:PMC5874404

19. Kim SK, Welsh RM. Comprehensive Early and Lasting Loss of Memory CD8 T cells and Functional Memory During Acute and Persistent viral infections. The Journal of Immunology 2004; 172(5):3139-50. doi: https://doi.org/ 10.4049/jimmunol.172.5.3139, PMid:14978120

20. Laksono BM, de Vries RD, Verburgh RJ, Visser EG, de Jong A, Fraaij PL, et al. Studies into the Mechanism of Measles-associated Immune Suppression During a Measles Outbreak in the Netherlands. Nature Communications 2018; 9 (1): 1-10. doi:https://doi.org/ 10.1038/s41467-018-07515-0, PMid:30470742 PMCid:PMC6251901

21. Petrova VN, Sawatsky B, Han AX, Laksono BM, Walz L, Parker E, et al. Incomplete Genetic Reconstitution of B Cell Pools Contributes to Prolonged Immunosuppression after Measles. Science Immunology 2019; 4(41):166-172. doi: 10.1126/sciimmunol.aay6125, PMid:31672862

22. Kerdiles YM, Sellin CI, Druelle J, Horvat B. Immunosuppression Caused by Measles Virus: Role of Viral Proteins. Reviews in Medical Virology 2006;16(1):49-63. doi: https://doi.org/10.1002/rmv.486, PMid:16237742

23. Mina MJ, Metcalf CJ, De Swart RL, Osterhaus AD, Grenfell BT. Long-term Measles-Induced Immunomodulation Increases Overall Childhood Infectious Disease Mortality. Science 2015; 348(6235):694-9. doi: 10.1126/science.aaa3662, PMid:25954009 PMCid:PMC4823017

24. de Vries RD, de Swart RL. Measles immune suppression: Functional Impairment or Numbers Game? PLoS Pathogens 2014; 10(12):e1004482. https://doi.org/10.1371/ journal.ppat.1004482, PMid:25522010 PMCid:PMC4270776

25. Paules CI, Marston HD, Fauci AS. Measles in 2019-Going Backward. New England Journal of Medicine 2019; 380(23):2185-2187. doi: 10.1056/ NEJMp1905099, PMid:30995368

26. Shanks GD, Lee SE, Howard A, Brundage JF. Extreme Mortality After First Introduction of Measles Virus to the Polynesian Island of Rotuma, 1911. American Journal of Epidemiology 2011;173(10):1211-22. doi:https://doi.org/ 10.1093/aje/kwq504, PMid:21498623

27. Servet-Delprat C, Vidalain PO, Azocar O, Le Deist F, Fischer A, Rabourdin-Combe C. Consequences of Fas-mediated Human Dendritic Cell Apoptosis Induced by Measles Virus. Journal of Virology 2000; 74(9):4387-93. doi: 10.1128/JVI.74.9.4387-4393.2000, PMid:10756053 PMCid:PMC111955

28. Mina MJ. Measles, Immune Suppression and Vaccination: Direct and Indirect Nonspecific Vaccine Benefits. Journal of Infection 2017; 74:10-7. https://doi.org/ 10.1016/S0163-4453(17)30185-8 
29. Centers for Disease Control and Prevention (2019). Progress Toward Regional Measles Elimination Worldwide, 2000-2018. Morbidity and Mortality Weekly Report 2019; 68:1105-1111. doi: https://doi.org/10.15585/ mmwr.mm6848a1, PMid:31805033 P MCid:PMC6897527

30. World Health Organization (2011). Outbreak News: Measles Outbreaks in Europe. Weekly Epidemiological Record 201186 (18):173-4. Available at: https://www.ncbi. nlm.nih.gov/pubmed/21608198 [Retrieved December 30, 2019].

31. World Health Organization (2019). Sustain Accelerate Innovate: Measles Elimination and Rubella Control in the WHO South-East Asia Region. Available at https://apps. who.int/iris/handle/10665/326852. [Retrieved December 31, 2019].
32. Mina MJ, Grenfell BT, Metcalf CJ. Response to Comment on "Long-term measles-Induced Immunomodulation Increases Overall Childhood Infectious Disease Mortality". Science 2019; 365(6449):eaax6498. doi: 10.1126/ science.aax 6498 .

33. Laksono BM, de Vries RD, Duprex WP, de Swart RL. Measles Pathogenesis, Immune Suppression and Animal Models. Current Opinion in Virology 2020; 41:31-7. doi: https://doi.org/10.1016/j.coviro.2020.03.002, PMid:32339942

34. Behrens L, Cherry JD, Heininger U. The Susceptibility to Other Infectious Diseases Following Measles During a Three Year Observation Period in Switzerland. The Pediatric Infectious Disease Journal 2020; 39(6)478-482. doi: 10.1097/INF.0000000000002599, https://doi.org/10.1097/INF. 0000000000002599 , PMid:32084116 